\title{
PENGGEMUKAN SAPI MENGGUNAKAN PAKAN TANPA HIJAUAN (COMPLETE FEED) DAN TAPE JERAMI SERTA GROWTH PROMOTOR STRATEGI PENCAPAIAN SWASEMBADA DAGING
}

\author{
FATTENING OF CATTLE USE WITHOUT FORAGE FEED (COMPLETE FEED) AND TAPE STRAW \\ FEED AND GROWTH PROMOTORS STRATEGY OF SUFFICIENCY OF MEAT ACHIEVEMENT
}

\author{
Wurlina \\ Fakultas Kedokteran Hewan \\ Mas'ud Hariadi \\ Fakultas Kedokteran Hewan \\ Imam Mustofa \\ Fakultas Kedokteran Hewan \\ Dewa Ketut Meles \\ Fakultas Kedokteran Hewan
}

\begin{abstract}
ABSTRAK
Program Kemitraan Masyarakat (PKM) yang dilakukan pada kelompok penggemukan sapi belum memenuhi syarat untuk menyelesaikan masalah 1) jerami padi sebagai pakan ternak 2) limbah pertanian dan limbah industri sebagai pakan tanpa hijauan 3) pengolahan jerami padi menjadi pita jerami 4) pengolahan limbah pertanian dan industri limbah menjadi pakan ternak tanpa hijauan 5) promotor pertumbuhan pengolahan berasal dari empon-empon dan pengambilan tanaman obat, dan 6) pembuatan kotoran sapi menjadi pupuk ramah lingkungan. Tujuan dari PKM adalah (1) untuk memproses jerami padi menjadi pita jerami sebagai pakan ternak bergizi (2) tanpa pengolahan pakan hijauan (pakan lengkap) (3) pengolahan promotor pertumbuhan (4) penggemukan sapi lokal menggunakan pita jerami dan pakan tanpa hijauan serta promotor pertumbuhan. Manfaat PKM adalah mengembangkan sumber daya manusia dan meningkatkan pendapatan penggemukan sapi lokal dengan biaya produksi lebih rendah. Metode yang digunakan dalam kegiatan PKM adalah pendidikan dan pelatihan penggemukan sapi lokal menggunakan tape jerami pakan dan pakan tanpa hijauan ditambah promotor pertumbuhan, pengolahan limbah menjadi pupuk ramah lingkungan pada UKMK anggota penggemukan sapi lokal di Tuban. Hasilnya adalah peningkatan berat sapi per sapi per hari pada sapi lokal sebesar 0,625 $\pm 0,048 \mathrm{~kg}$, sapi peranakan ongole $0,924 \pm 0,067 \mathrm{~kg}$, sapi limusin hibrida untuk 1,673 \pm $0,068 \mathrm{~kg}$ dan sapi potong silang Simmental sebesar 2,105 $\pm 0,414 \mathrm{~kg}$.
\end{abstract}

Kata kunci: pakan lengkap, pita jerami, promotor pertumbuhan, sapi lokal, pupuk

\section{ABSTRACT}

Program Kemitraan Masyarakat (PKM) which performed on a group of cattle fattening is not qualified yet to solve the problems 1) rice straw as animal feed 2) agricultural waste and industrial waste as feed without forage 3) processing of rice straw into straw tape 4) processing agricultural waste and industrial waste into animal feed without forage 5) processing growth promotor derived from empon-empon and retrieval medicinal plants, and 6) making of cow manure waste into environmentally friendly fertilizer. The purposes of PKM are (1) to process of rice straw into straw tape as a nutritious animal feed (2) without forage feed processing (complete feed) (3) processing of growth promotors (4) local cattle fattening using tape straw and feed without forage as well as growth promotor. Benefits of PKM is to develop human resources and increase income of fattening local cattle farmers with lower production costs. The method used in PKM activities are education 
and training of local cattle fattening using tape straw feed and feed without forage plus growth promotor, processing waste into environmentally friendly fertilizer on UKMK of local cattle fattening members in Tuban. The result is enhancement of cattle weight per cow per day on local cattle amounted to $0.625 \pm 0.048 \mathrm{~kg}$, ongole crossbreed cattle $0.924 \pm 0.067 \mathrm{~kg}$, hybrid limousine cattle for $1.673 \pm 0.068 \mathrm{~kg}$ and Simmental crossbreed cattle of $2.105 \pm 0.414 \mathrm{~kg}$.

Keywords: complete feed, straw tape, growth promotors, local cattle, fertilizer

\section{PENDAHULUAN}

Pada tahun 2020 mendatang, diperkirakan tingkat konsumsi daging sapi masyarakat Indonesia akan meningkat dari 1,8 kg/kapita/tahun menjadi $2,5 \mathrm{~kg} / \mathrm{kapita} /$ tahun. Kenaikan konsumsi itu setara dengan pemotongan 2,2 juta ekor ternak sapi. Ini berarti diperlukan tambahan 100.000 ekor sapi potong baru setiap bulan yang berasal dari peternakan rakyat. Kebutuhan daging sapi saat ini diperkirakan +781.000 ton, sedangkan produksi daging sapi Nasional hanya dapat memenuhi sekitar 434.300 ton yang dipenuhi dari peternakan sapi rakyat, sehingga terjadi kekurangan sebanyak 248.700 ton. Dengan demikian kebutuhan akan daging sapi telah jauh melampaui laju produksi sapi lokal sehingga kekurangannya harus dipenuhi dengan impor sapi dan daging beku (Wurlina dkk., 2007, Ratnani dkk., 2007). Mengingat pertumbuhan populasi sapi potong nasional hanya berkisar $0,98 \%$ diperkirakan akan terjadi pengurasan atau eksploitasi yang tidak terkendali terhadap ternak lokal rakyat, yang pada akhirnya akan mengganggu keseimbangan populasi ternak nasional.

Secara nasional wilayah propinsi Jawa Timur merupakan salah satu pengembangan peternakan sapi potong yang sangat potensial. Hal ini ditunjang oleh ketersediaan bahan pakan yang bersumber dari limbah pertanian. Kebiasaan masyarakat yang menjadikan ternak sapi potong sebagai alternatif untuk memenuhi kebutuhan ekonomi keluarga maupun sebagai ternak kerja di pertanian. Wilayah Jawa Timur mampu berswasembada daging sapi, bahkan mampu menyuplai kebutuhan daging keluar propinsi. Kegiatan usaha ternak diupayakan untuk memanfaatkan limbah pertanian dengan memadukan antara usaha ternak dengan usaha tani merupakan suatu sistem.

Pakan hijauan merupakan salah satu faktor yang penting dalam usaha peternakan terutama pada penggemukan sapi potong, karena hampir $70 \%$ total biaya produksi adalah biaya pakan. Pakan hijauan sulit didapat pada musim kemarau, belum lagi mahalnya pakan tambahan berupa konsentrat. Apabila sapi diberi pakan rumput basah dibutuhkan $+40 \mathrm{~kg}$ /ekor/hari dan pakan konsentrat $5 \mathrm{~kg}$ dan growth promotor buatan pabrik, sehingga biaya untuk kebutuhan pakan sangat mahal. Tetapi dengan menggunakan pakan dari limbah pertanian, perkebunan dan industri yang difermentasi dan growth promotor asal empon-empon untuk pakan dapat ditekan.

Upaya penggemukan sapi bakalan secara cepat dengan pakan tanpa hijauan atau tape jerami dan tambahan growth promotor diharapkan dapat meningkatkan berat badan sapi secara cepat sehingga kebutuhan sapi dapat terpenuhi sekaligus dapat mengurangi ketergantungan impor daging sapi maupun sapi bakalan yang pada akhirnya akan menghemat devisa negara.

Tujuan Program Kemitraan Masyarakat pada UMKM sapi adalah pengolahan tape jerami, pengolahan pakan tanpa hijauan (complete feed), pengolahan growth promoter, penggemukan sapi potong lokal, peranakan ongole, peranakan LImousin dan peranakan Simental dengan sistem kereman. Manfaat dari Program Kemitraan Masyarakat adalah manfaat bagi tim pelaksana dan perguruan tinggi adalah memperkaya wawasan tim pelaksana tentang penggemukan sapi potong yang dilakukan oleh pengusaha mitra, tempat sarana diskusi antara pelaksana kegiatan, pengusaha mitra dan mahasiswa dalam memecahkan masalah teknis dan pemasaran sapi potong dan Perguruan Tinggi dapat memfungsikan pelaksananya secara integral untuk melatih kegiatan kewirausaha bagi mahasiswa yang berorientasi agribisnis. Manfaat bagi UMKM adalah meningkatkan volume produksi karena pengusaha mendapat tambahan tenaga kerja dari mahasiswa, mendapat masukan dari Tim pelaksana dan dari mahasiswa peserta PKM tentang pakan sapi menggunakan bahan baku pakan lokal yaitu pakan tanpa hijauan, mendapat kontribusi positif sehubungan dengan keselamatan dan kesehatan pekerja, manajemen pemeliharaan dan pencegahan serta pengobatan penyakit. Manfaat bagi mahasiswa dari sisi keterampilan dan manajemen adalah keterampilan penggemukan sapi menjadi meningkat karena mahasiswa terlibat secara langsung pengolahan pakan sapi, alih teknologi dan transfer pengetahuan khususnya cara penggemukan sapi potong yang dihasilkan oleh pengusaha UMKM, calon wirausaha baru sesuai dengan basis iptek yang dimiliki yaitu pengolahan pakan dan growth promotor, pembuatan pupuk ramah lingkungan, menguasai aspek teknologi, manajemen (pemasaran, keuangan dan personalia). 


\section{METODE PELAKSANAAN}

Metode yang digunakan Program Kemitraan Masyarakat pada UMKM sapi potong adalah sebagai berikut 1) Pembekalan Ilmu Pengetahuan tentang pemeliharaan sapi yang meliputi: pengenalan ragam sapi potong, pengenalan sapi Limousin dan Simmental, pembuatan tape jerami dan pakan tanpa hijauan, growth promotor dan pencegahan penyakit. 2) Praktek pembuatan pakan ternak asal jerami dan pakan tanpa hijauan, pembuatan growth promotor asal empon-empon dan temu-temuan. Mengukur keberhasilan PKM adalah pembuatan pakan tanpa hijauan, growth promotor empon-empon dan temu-temuan yaitu peningkatan berat badan sapi per ekor per hari Evaluasi keberhasilan PKM pada anggota UMKM penggemukan sapi potong adalah setelah dilaksanakan pendidikan dan pembinaan serta pelatihan usaha penggemukan sapi potong kereman dengan menggunakan sumber bahan baku pakan lokal yaitu keterampilan pembuatan pakan tape jerami, pakan tanpa hijauan dan growth promoter, mencatat pertambahan berat badan penggemukan sapi lokal, peranakan Onggole, peranakan Limousin dan Simmental hingga sapi tersebut siap untuk dijual.

\section{HASIL DAN PEMBAHASAN}

\section{Pengolahan dan Analisis Pakan}

Peserta pendidikan dan pelatihan peternakan penggemukan sapi potong adalah anggota UMKM sapi potong . Bentuk kegiatan selain pengolahan tape jerami dan pakan ternak tanpa hijauan sebagai pakan ternak dan pengolahan tanaman obat sebagai growth promotor, hasilnya dapat dilihat pada tabel 1,2 dan 3

Pada tabel 1. terlihat kadar protein kasar pada rumput sebesar $2.52 \%$ dan jerami $2.58 \%$. Pada dasarnya ternak ruminansia mampu mensintesis protein dari bahan makanan yang berkualitas rendah seperti rumput dan jerami, karena dalam rumennya terdapat mikroorganisme yang menghasilkan enzim proteolitik, cellulase, dan hemicellulose, sehingga pengolahan jerami padi ini mengikuti pola kerja dari mikroorganisme rumen. Walaupun jerami padi yang miskin akan zat-zat makanan, namun sekitar 40 persen dapat dicerna sebagai sumber energi dalam proses pencernaan ternak. Rendahnya daya cerna ini disebabkan oleh adanya Lignin dan silika yang mengikat Cellulosa dan Hemicellulosa dalam bentuk ikatan rangkap, sehingga sukar dicerna oleh enzim dari mikroorganisme dalam rumen (Komar, 2003).

Serat kasar secara fisik dan kimia menjadi salah satu faktor penyebab ternak tidak mampu mencerna bahan pakan tersebut. Peternak pada umumnya menggunakan konsentrat sebagai pakan sumber energi bagi ternak. Konsentrat merupakan campuran bahan pakan ternak yang mutu gizinya baik dengan kandungan protein cukup tinggi dengan kandungan serat kasar rendah dan mudah dicerna oleh ternak. Konsentrat ditambahkan ke dalam pakan untuk meningkatkan gizi, namun harga konsentrat untuk pakan ternak tergolong mahal sehingga kurang efisien untuk peternak rakyat. Dedak padi dan onggok merupakan jenis pakan sumber energi yang bisa digunakan oleh peternak sebagai pengganti konsentrat karena harganya yang murah dan mudah didapat. Onggok mengandung protein kasar 2,95\%, lemak 0,35\%, serat kasar 7,28\% dan BETN 71,64\%. Substitusi onggok sebagai bahan pakan masih dihadapkan pada masalah rendahnya kandungan protein dan rendahnya kecernaan (Anshari, 2010).

Pada tabel 2 terlihat protein kasar dari tape tebon sebesar $8.91 \%$ dan tape jerami sebesar $7.87 \%$. Pemanfaatan jerami padi sebagai pakan ternak telah banyak dilakukan dengan berbagai cara, diantaranya yang menguntungkan dan mudah dilaksanakan adalah cara kimia dengan mencampur jerami padi dengan larutan urea, molase dan fermentor. Hasil campuran inilah disebut Jerami padi amoniasi atau lebih dikenal dengan tape jerami (Komar, 2003). Mikroorganisme dalam rumen akan berkembang biak secara maksimal apabila tersedia protein kasar yang cukup $8-10 \%$ dalam ransum. Hasil akhir metabolisme dalam rumen adalah

Tabel 1. Hasil Analisis Pakan Hijauan

\begin{tabular}{lccccccccc}
\hline \multirow{2}{*}{$\begin{array}{c}\text { Pakan } \\
\text { ternak }\end{array}$} & $\begin{array}{c}\text { Bahan } \\
\text { kering }\end{array}$ & Abu & $\begin{array}{c}\text { Protein } \\
\text { Kasar }\end{array}$ & $\begin{array}{c}\text { Lemak } \\
\text { Kasar }\end{array}$ & $\begin{array}{c}\text { Serat } \\
\text { Kasar }\end{array}$ & Ca & \multirow{2}{*}{ BETN } & TDN \\
\hline Rumput & 35,20 & 5,81 & 2,88 & 2,52 & 16,55 & 2,06 & 7,43 & 22,36 \\
Jerami & 26,59 & 1,68 & 2,26 & 2,58 & 7,31 & 1,31 & 12,74 & 21,66 \\
\hline
\end{tabular}

Tabel 2. Hasil Analisis Pakan Tape Jerami/Tebon

\begin{tabular}{cccccccccc}
\hline \multirow{2}{*}{$\begin{array}{c}\text { Pakan } \\
\text { ternak }\end{array}$} & $\begin{array}{c}\text { Bahan } \\
\text { kering }\end{array}$ & Abu & $\begin{array}{c}\text { Protein } \\
\text { Kasar }\end{array}$ & $\begin{array}{c}\text { Lemak } \\
\text { Kasar }\end{array}$ & $\begin{array}{c}\text { Serat } \\
\text { Kasar }\end{array}$ & Ca & BETN & TDN \\
\hline Tape Tebon & 56,77 & 6,65 & 8,91 & 3,77 & 16,00 & 0,97 & 21,43 & 41,94 \\
Tape Jerami & 44,81 & 4,60 & 7,87 & 3,55 & 13,83 & 1,14 & 14,94 & 33,84 \\
\hline
\end{tabular}


Tabel 3. Hasil Analisis Pakan Ternak Tanpa Hijauan (Complete Feed)

\begin{tabular}{|c|c|c|c|c|c|c|c|c|}
\hline \multirow{2}{*}{$\begin{array}{l}\text { Pakan } \\
\text { ternak }\end{array}$} & \multicolumn{8}{|c|}{ Hasil Analisis Pakan Tanpa Hijauan (Complete Feed) (\%) } \\
\hline & $\begin{array}{l}\text { Bahan } \\
\text { kering }\end{array}$ & Abu & $\begin{array}{c}\text { Protein } \\
\text { Kasar }\end{array}$ & $\begin{array}{c}\text { Lemak } \\
\text { Kasar }\end{array}$ & $\begin{array}{l}\text { Serat } \\
\text { Kasar }\end{array}$ & $\mathrm{Ca}$ & BETN & TDN \\
\hline Pakan 1 & 87,77 & 9,76 & 10,01 & 10,56 & 31,52 & 0,14 & 25,90 & 67,38 \\
\hline Pakan 2 & 93,59 & 10,37 & 10,53 & 6,22 & 32,08 & 1,11 & 34,36 & 67,56 \\
\hline Pakan 3 & 87,50 & 10,24 & 10,62 & 4,17 & 16,50 & 0,97 & 45,95 & 69,57 \\
\hline Pakan 4 & 74,41 & 8,89 & 9,23 & 8,16 & 12,51 & 0,58 & 35,61 & 68,35 \\
\hline Pakan 5 & 90,44 & 10,22 & 10,34 & 5,47 & 17,30 & 0,93 & 47,10 & 68.72 \\
\hline
\end{tabular}

amoniak (asal protein) untuk sumber protein dan asam lemak tak jenuh (asal serat kasar) sebagai sumber energi. Amoniak akan berperan pada proses hidrolisa ikatan cellulose, menghancurkan ikatan Lino-hemicellulosa, (khusus jerami padi juga melarutkan sebagai silika), terjadinya pengikatan Nitrogen pada jerami padi, maka kandungan protein kasar jerami akan meningkat. Pada akhirnya peranan NH3 (Amoniak) ialah untuk membebaskan cellulosa dari ikatan lignin yang tak dapat dicerna dengan demikian maka mikroorganisme dalam rumen dapat mencerna serat kasar tersebut dengan baik (Mariyono dan Romjali, 2007, Samosir dan Solo, 2002).

Pada tabel 3. terlihat perbedaan pakan tanpa hijauan untuk sapi potong adalah pada pakan tidak menggunakan limbah kelapa sawit (pakan 1 dan pakan 4) sedangkan pada pakan 2, 3 dan 5 menggunakan limbah kelapa sawit. Peningkatan berat badan antara pakan 1 dan 2 ternyata tidak terdapat perbedaan dan telah dapat meningkatkan berat badan pada sapi lokal, sapi peranakan ongole, sapi peranakan Limousin dan sapi peranakan Simmental. Hasil dari analisis pakan program Kemitraan Masyarakat adalah protein kasar antara $7-10 \%$. Kandungan protein kasar yang kurang dari $7 \%$ akan membuat aktivitas mikrobia rumen tertekan karena kekurangan amonia sehingga menurunkan pencernaan karbohidrat sehingga dapat mempengaruhi kandungan asam lemak tak jenuh yang dihasilkan. Sebaliknya, apabila kadar amonia di dalam rumen terlalu tinggi maka absorbsi amonia di dalam hati berlebihan sehingga perubahan urea menjadi lambat. Akibatnya, kadar amonia dalam peredaran darah perifer menjadi naik dan terjadi keracunan yang dapat mengakibatkan kematian (Mahrun-Nisa, 2004).

Limbah pertanian, perkebunan dan agroindustri pertanian memiliki potensi yang cukup besar sebagai sumber pakan ternak (Mariyono dan Romjali, 2007). Jenis limbah pertanian yang sering digunakan sebagai pakan ternak adalah jerami padi, karena tersedia dalam jumlah besar, harganya murah serta berkesinambungan. Menurut Lahay dan Rinduwati (2007) sumber pakan ternak sebaiknya lebih murah, berkesinambungan, bergizi baik dan tidak bersaing dengan kebutuhan manusia. Jerami padi merupakan sisa dari pemanenan padi yang terdiri dari batang dan daun. Jerami padi memiliki kandungan protein kasar lebih rendah daripada rumput sedangkan kandungan serat kasarnya lebih tinggi. Serat jerami padi sebagian besar berikatan dengan lignin dan silika yang mencapai 13 persen dari bahan kering. Tingginya lignin dan silika ini berdampak menyebabkan rendahnya kecernaan.

Menurut Murni et al. (2008), permasalahan dari pemanfaatan limbah pertanian dan perkebunan sebagai pakan ternak adalah nilai nutrisi dan tingkat kecernaan yang rendah. Dedak padi mengandung $10,6 \%$ air, 4,1\% protein, $32,4 \%$ bahan ekstrak tanpa N, 35,3\% serat kasar, 1,6\% lemak dan 16\% abu (Supriyadi, 2013). Onggok dan dedak padi cukup potensial untuk dimanfaatkan sebagai pakan sumber energi dalam ransum ternak. Namun rendahnya nutrisi yang terkandung pada onggok dan dedak padi menjadikan aktivitas mikroba dalam rumen kurang optimal. Salah satu cara untuk meningkatkan kinerja mikroba rumen adalah dengan memberikan pakan Penunjang Kinerja Mikroba rumen (PKM) dalam ransum untuk meningkatkan kecernaan dan kandungan nutrisi bahan pakan. Molases digunakan sebagai bahan pakan sumber energi (C), urea sebagai sumber N. Pakan sumber energi dapat mensuplai unsur karbon yang dapat dimanfaatkan oleh mikroba. Imbangan $\mathrm{C} / \mathrm{N}$ yang cukup tetap dapat menumbuhkan bakteri dalam rumen. Imbangan Carbon $(\mathrm{C})$ dan Nitrogen $(\mathrm{N})$ yang terkandung dalam bahan organik sangat menentukan kehidupan dan aktivitas mikroorganisme.

Peningkatan berat badan sapi potong menggunakan pakan tanpa hijauan/ tape jerami dan growth promotor Sapi lokal, Sapi peranakan onggole (PO), sapi jenis Limousin dan Simmental masing-masing sebanyak 10 ekor diberi pakan tanpa hijauan. Untuk merangsang peningkatan berat badan diberi Growth promotor tanaman obat sebanyak $20 \mathrm{ml}$ setiap hari. Semua sapi sebelum diberi pakan tanpa hijauan ditimbang dulu berat badannya, kemudian digemukkan selama 4 bulan. Setelah 4 bulan berat badan sapi ditimbang kembali, dan dihitung peningkatan berat badannya rata rata per hari. Hasil peningkatan berat badan per hari dapat dilihat pada tabel 4 . 
Tabel 4. Peningkatan Berat Badan Sapi

\begin{tabular}{lc}
\hline \multicolumn{1}{c}{ Jenis sapi } & $\begin{array}{c}\text { Rerata peningkatan berat } \\
\text { badan per hari (kg) }\end{array}$ \\
\hline Sapi lokal & $0,625 \pm 0,048$ \\
Peranakan Ongole (PO) & $0,924 \pm 0,067$ \\
Peranakan Limousin (PL) & $1,673 \pm 0,068$ \\
Peranakan Simmental (PS) & $2,105 \pm 0,414 \mathrm{E}$ \\
\hline
\end{tabular}

Dari Tabel 4 dapat diketahui bahwa sapi peranakan Simmental mempunyai peningkatan berat badan tertinggi dibandingkan sapi peranakan Limousin, peranakan Onggol dan sapi lokal. Sapi diberi makan rumput maka diperlukan pakan hijauan $10 \%$ dari berat badan atau sebanyak $35-$ $40 \mathrm{~kg} /$ ekor/hari ditambah dengan konsentrat sehingga menyebabkan biaya pakan tinggi. Apabila pakan sapi berupa pakan tanpa hijauan maka dibutuhkan hanya 8-10 kg/ekor/ hari, sehingga akan menekan biaya pakan.

Pemberian pakan tanpa hijauan dan growth promotor pada keempat jenis sapi seharusnya peningkatan berat badannya sama. Namun kenyataannya sapi potong peranakan Simmental mempunyai pertumbuhan berat badan terbaik. Hal ini disebabkan sifat genetik sapi peranakan Simental mempunyai berat hingga mencapai 1,3 ton pada umur 4 tahun. Penambahan growth promotor asal empon-empon dan temu-temuan dapat merangsang pertumbuhan sehingga dapat menyebabkan peningkatan berat badan pada sapi peranakan simmental dan Limousin. Hal ini disebabkan kandungan kurkumin dan minyak atsiri. Kurkumin yang terdapat pada temu-temuan dapat menambah nafsu makan dan mempermudah absorbsi pakan dalam usus halus. Sedangkan minyak atsiri mempunyai bau dan rasa yang dapat menstimulasi syaraf pusat agar nafsu makan meningkat. Keberadaan minyak atsiri dapat menstimuli cairan pencernaan yang menghasilkan $\mathrm{pH}$ yang sesuai dengan enzim pencernaan seperti peptinase sehingga akan menurunkan terjadinya penyakit diare dan penyakit pencernaan lain (Widiastuti, 2014). Dalam saluran pencernaan terdapat banyak bakteri, protozoa, cacing dan fungi. Pemberian growth promoter yang mengandung jahe, kunyit dan temulawak mempunyai aktivitas antibakteri dan antifungi, yang terdapat pada minyak atsiri sehingga akan menyebabkan daya serap baik akan meningkatkan berat badan. Minyak atsiri sejak zaman dahulu digunakan untuk pencegahan perkembangan bakteri dan fungi dan digunakan sebagai pengganti antibiotik sehingga mempengaruhi populasi mikroba tetapi juga berpengaruh terhadap aktivitas enzim pencernaan dan meningkatkan metabolisme (Retnaningati, 2003). Manfaat pemberian jamu herbal pada ternak yaitu dapat mengoptimalkan daya kerja bakteri dalam rumen sehingga pakan dapat terserap maksimal, pertumbuhan harian optimal, kotoran lebih kering dan tidak berbau sehingga populasi lalat dalam kandang juga akan berkurang.

\section{KESIMPULAN DAN SARAN}

\section{Kesimpulan}

1. Tape jerami dan pakan tanpa hijauan dapat digunakan sebagai pakan sapi utamanya saat musim kemarau berkepanjangan

2. Growth promotor empon-empon dapat merangsang pertumbuhan berat badan sapi.

3. Peningkatan berat badan per hari antara sapi lokal, sapi PO, Limousin dan Simmental berturut-turut adalah 0,625 $\pm 0,048 \mathrm{~kg} / \mathrm{ekor} /$ hari, $0,924 \pm 0,067 \mathrm{~kg} / \mathrm{ekor} / \mathrm{hari}, 1,673 \pm$ $0,068 \mathrm{~kg} / \mathrm{ekor} /$ hari dan 2,105 $\pm 0,414 \mathrm{~kg} / \mathrm{ekor} /$ hari.

\section{Saran}

1. Kegiatan Program Kemitraan Masyarakat, hendaknya dilakukan secara berkesinambungan untuk menguatkan UMKM hingga dapat menyerap tenaga kerja.

2. Hendaknya melibatkan mahasiswa guna meningkatkan jiwa wirausaha, agar setelah lulus nanti mereka dapat mandiri, menciptakan lapangan kerja dan sebagai entrepreneurship.

\section{UCAPAN TERIMA KASIH}

Terima kasih kepada Direktorat Riset dan Pengabdian Masyarakat. Direktorat Jenderal Penguatan Riset dan Pengembangan Kementerian Riset, Teknologi, dan Pendidikan Tinggi. Sesuai dengan Surat Perjanjian Pendanaan Pelaksanaan Program Pengabdian Masyarakat Tahun Anggaran 2017. Nomor:004/SP2H/PPM/DRPM/ $\mathrm{V} / 2017$.

\section{DAFTAR PUSTAKA}

Anshari, M.F. 2010. Pengaruh Pengukusan Onggok dan Suplementasi Methionine Hidroxy Analog dalam Ransum Terhadap Performan Domba Lokal Jantan. Naskah Publikasi. Fakultas Pertanian. Universitas Sebelas Maret. Surakarta.

Komar. 2003. Teknologi pengolahan jerami padi sebagai makanan ternak, Yayasan Dian Grahita, Studio Anissa, Jakarta.

Lahay, N. dan Rinduwati. 2007. Meningkatkan Nilai Nutrisi Feses Broiler dan Feses Puyuh dengan Teknologi Efektivitas Mikroorganisme sebagai Bahan Pakan 
Broiler. Seminar Nasional Teknologi Peternakan dan Veteriner. Bogor. hlm. 567-571.

Mahr-un-Nisa, Sarwar, M., and Khan, M. A. 2004. Nutritive value of urea treated wheat straw ensiled with or without corn steep liquor for lactating nili-ravi buffaloes. AsianAust. J. Anim. Sci. 17(6): 825-829.

Mariyono dan Romjali E. 2007. Petujuk Teknis Teknologi Pakan Murah Untuk Usaha Pembibitan Sapi Potong. Pusat Penelitian dan Pengembangan Peternakan. Pasuruan.

Murni, R., Suparjo, Akmal dan B. L. Ginting. 2008. Klasifikasi Limbah untuk Bahan akan Ternak. Buku Ajar Teknologi Pemanfaatan Limbah untuk Pakan. aboratorium Makanan Ternak Fakultas Peternakan Universitas Jambi.

Ratnani H, Wurlina, Meles DK. 2007. Pengolahan jerami menjadi tape jerami di kabupaten Probolinggo. LPM Unair. Surabaya.
Retnaningati T. 2003. Potensi Tepung Jahe, Kunyit dan Temulawak Sebagai Pakan Tambahan Terhadap Konsumsi Pakan, Pertambahan Berat Badan dan Konversi Pakan Pada. Ayam pedaging jantan. FKH Unair. Skripsi.

Samosir, Solo SR. 2002. Pengelolaan Lahan Kering, Jurusan Ilmu Tanah Fakultas Pertanian dan Kehutanan, UNHAS.Makassar.

Sunarni, Wurlina dan Dewa Ketut Meles.15. Materi Ipteks Bagi Masyarakat “ Jamu dan Tanaman Obat”.

Supriyadi. 2013. Macam Bahan Pakan Sapi dan Kandungan Gizinya. Badan Penelitian dan Pengembangan Pertanian DIY. Yogyakarta.

Widiastuti, A. 2014. Teknologi Jamu Herbal untuk Ternak. Badan Litbang Pertanian Kementrian Pertanian RI (BPTP) Yogyakarta.

Wurlina, Meles D.K, Rachmawati K. 2007. Materi pendidikan dan pelatihan penggemukan sapi. Pengolahan growth promotor LPM Unair. Surabaya. 